\title{
ARTIKELEN
}

\section{Alternative Methodologies: Learning Critique as a Skill}

\author{
Bal Sokhi-Bulley
}

\section{Introduction}

Halfway through the year of postgraduate studies that is required for the LLM at Queen's University Belfast, I give a talk to the students, entitled 'Asking the Right Questions: Understanding Methodology'. It is not always particularly well received. On one occasion I was approached by a student afterward, who commented, "All that "how questions" stuff confused the hell out of me. You should really think about whether we need to know that. Oh, and don't talk about Foucault!' In direct resistance to this comment, let me begin this article with a quotation from Foucault's essay 'What is Critique', where he describes the art of critique as 'a certain way of thinking, speaking and acting, a certain relationship to what exists, to what one knows, to what one does, a relationship to society, to culture and also a relationship to others, that we would call, let's say, the critical attitude' (Foucault 1997, p. 24). These are features of methodology - that is, of how to think (speak and act) a project. And so had this student engaged with my talk she might have seen that this is precisely the crucial importance of understanding methodology and being able to define it: it is your approach, your perspective, your attitude; it is, essentially, how you think. Thus it is about asking 'the right questions' for you, for your project and what interests you and these are 'how' questions. The 'how' question examines how meanings are produced and attached to various social subjects and objects, thus, as Roxanne Lyn Doty explains, 'constituting particular interpretative dispositions that create certain possibilities and preclude others' (Doty 1996, p. 4). It influences the research questions that you ask and it challenges assumptions. It determines, in other words, your 'critical attitude'.

This article stresses the importance and possibility of training the critical attitude. It suggests that the critical attitude, or what Foucault also calls 'critique', are characteristics of methodology - that is, of how to think a project. It is crucial that as researchers we are able to articulate our methodologies. It is also crucial that as educators, we can teach our students why they need to articulate the way in which they think. Can we therefore teach, the article asks, critical legal education? I suggest here that the way to do this is to market methodology as a 'skill' - and to thereby free it to some extent from what both students and researchers in Law often view as the negative connotations of 'theory'. 
I begin by addressing the issue of why it is difficult to teach critical legal education. It is necessary then to tackle questions of how to define (alternative) methodology - and how exactly it is different from 'theory' and indeed from 'method'. The second section of the article then presents the need to market methodology as a 'skill' to our law students - as a 'transferrable' skill that translates to the practical workplace and also as a means of seeing alternative truths in the practice and understanding of law and society. It discusses this as a way of hopefully producing a student that is not docile and disengaged (despite being, nevertheless, a successful lawyer) but, rather, is able to nurture an attitude that allows for 'thinking' (law) critically.

\section{The difficulty in teaching critical legal education: what is methodology?}

\subsection{The apathetic attitude}

The struggle for 'a radical egalitarian alternative vision of what legal education should become' by observing it through the lens of Critical Legal Studies (CLS) has already famously been identified by Duncan Kennedy in his 'little red book', first published as a pamphlet in 1983, entitled Legal Education and the Reproduction of Hierarchy (Kennedy 2004, p. 1). Kennedy makes a 'utopian proposal' to help reduce illegitimate hierarchy and the feelings of alienation that students feel within law schools (p. 136-139). My article aims to engage in a slightly different struggle - that of making researchers and educators (and in turn students) think differently about how they teach (and read) law. It perhaps interprets 'critical' too loosely as an 'art of critique' and a certain 'curiosity' - which is an important word, since:

'the word [curiosity](...) evokes "care"; it evokes the care one takes of what exists and what might exist; a sharpened sense of reality, but one that is never immobilised before it; a readiness to find what surrounds us strange and odd; a certain determination to throw off familiar ways of thought and to look at the same things in a different way; a passion for seizing what is happening now and what is disappearing; a lack of respect for the traditional hierarchies of what is important and fundamental' (Foucault 2000, p. 325; emphasis added).

Panu Minkkinen also addresses the question 'what does it mean to be critical' when talking of 'critical legal method' (Minkkinen 2013, p. 119). Surely all research, at the doctoral level anyway, should be 'critical' in the sense that it employs 'critical judgement (...) a generic intellectual skill that all researchers are supposed to be able to apply in relation to the object of their research' (ibid.). Minkkinen points us to an understanding of 'critical' that echoes the association I make with Foucault's 'curiosity'; he uses Habermas to speak of being 'critical' as 'self-reflection', a 'concern with knowledge' that is 'emancipatory': 
'The methodological frame which settles the meaning of the validity of this category of critical statements can be explained in terms of the notion of selfreflection. This frees the subject from dependence on hypostatized forces. Self-reflection is influenced by an emancipatory concern with knowledge (...)' (Habermas 1966).

Thus for my purposes, the 'critical' in 'critical legal education' refers to a concern with nurturing 'curiosity' and 'self-reflection' - to developing a 'critical attitude' to what one studies and the questions one asks of it.

My interest in the way in which the 'art of critique' is (not) nurtured in law schools began in 2007 when I started work on an AHRC-sponsored project on legal research methodologies in European Union and International Law with two colleagues at the University of Nottingham. ${ }^{1}$ The impetus for the project, initiated by Professor Hervey, was a general experience that something was 'missing' from these disciplines - in that students did not reflect on their research: on where it fits in with the discipline, what kinds of research questions they think are interesting to ask, what theoretical perspective best supports their way of thinking about their project, and so on. They had no awareness, in other words, of methodology. Moreover, there was not sufficient guidance available for the more curious amongst them that were in fact interested in reflecting on these issues. It was also our experience that staff within law schools (the researchers and the educators) were often themselves, having been nurtured in a dominantly doctrinal environment, at a loss as to how to explain to students not only the importance of these questions but also how to explain 'methodology'.

In order to substantiate our experiences, we ran two workshops for $\mathrm{PhD}$ students (attended mainly by those beginning or at the early stages of study) and consulted numerous scholars across ten partner institutions on a set of materials that eventually were published in a book, entitled Research Methodologies in EU and International Law (Cryer, Hervey and \& Sokhi-Bulley 2011). What we found over the course of the process was interesting: first, some academic staff either did not know about, or had little interest in knowing about, methodology. Second, most $\mathrm{PhD}$ students were beginning their research without any knowledge of methodology or the opportunity to think about the practice of research and its theoretical implications. Third, and most interestingly for us, the feedback on the workshops was extremely positive, with students commenting, for instance, that (Cryer, Hervey and \& Sokhi-Bulley 2008, p. 48):

1 Professor Tamara Hervey, Jean Monnet Professor of European Union Law, University of Sheffield; Professor Robert Cryer, Professor of International and Criminal Law, University of Birmingham. For a background to the project, see Cryer, Hervey \& Sokhi-Bulley 2011. It is fair to say that my personal concern here (and indeed that of the project at the time) is law schools in the United Kingdom only. 
'This workshop has turned me into a theorist'

'My assumptions about theories/methodologies have changed'

'[The workshop] made me focus on methods and theory'

This latter point reveals that a majority of students, once exposed to different perspectives, approaches or what I am calling 'alternative methodologies', are actually interested in learning about them. The point is that many did not understand, first, what a methodology is - are there different types of methodologies and how do you 'choose' your methodology? How, moreover, do you articulate your methodology? Second, why is methodology important? That is, many see it as an added complication to their research projects, rather than a necessary part of good research.

Perhaps a reason explaining why students feel this way is that in most law schools law is taught in a traditionally doctrinal sense. ${ }^{2}$ Subjects such as legal theory, legal philosophy or jurisprudence, are typically considered 'peripheral subjects' (Kennedy 2004, p. 37) - as opposed to the 'core subjects' that make up qualifying law degrees (such as Land Law, Criminal Law and European Union Law). This is relevant as 'methodology' has significant connotations of 'theory', as I discuss below.

Another reason may be that there is no real accepted cannon of 'approaches to law' or 'legal methodologies'. This is in stark contrast to disciplines such as International Relations or Politics, where texts such as Scott Burchill et al.'s Theories of International Relations outline a series of typically used approaches to the subject that students are taught to become familiar with (from, Realism, Liberalism and Constructivism to Critical Theory, Feminism and Poststructuralism). ${ }^{3}$ The classic 'jurisprudence' textbook has assumed that 'legal positivism' is 'the "properly" legal perspective, ${ }^{4}$ focusing on this (and on natural law theories) with perhaps a couple of chapters at the end on 'other' approaches (this, as I explain below, is what I call 'alternative methodologies'). For instance, Penner et al.'s Introduction to Jurisprudence and Legal Theory has a chapter on Foucault and law, a chapter on feminism and law, and a chapter on autopoesis. McCoubrey and White's Textbooks on Jurisprudence includes an all-encompassing last chapter on 'postmodern legal theory'. ${ }^{5}$ Ratnapala offers an interesting arrangement in his book, Jurisprudence, splitting Part 1 (Law as it is) from the remainder of the book, which examines what the law ought to be (Part 2: Law and morality; Part 3: Social dimensions of law; Part 4: rights and justice). Others, such as the excellent Critical Jurisprudence by Douzi-

2 This article uses 'doctrinal' and 'legal positivism' synonymously. I make this association since legal positivism, as a methodology, is interested in questions concerning the description and explanation of law as it is, in empirical observation. For a similar understanding of the relation between the two terms, see Cryer, Hervey \& Sokhi-Bulley 2011, p. 38 and Minkkinen 2013, p. 123. For an interesting alternative analysis of the meaning and value of 'doctrinal' methodology, see Hutchinson 2013, p. 7.

3 Burchill et al. 2009. See also Dunne, Kurki \& Smith 2013 and Steans et al. 2010.

4 Minkkinen 2013, p. 119, who takes this from Hart. See further Hart 2012.

5 McCoubrey \& White 1999. See also the revised and updated version, Penner \& Melissaris 2012. 
nas and Gearey would simply be considered 'too alternative' by some for its storytelling, CLS style.

The term 'jurisprudence' is often used synonymously with legal theory - it thus 'consists of scientific and philosophical investigations of the social phenomenon of law and of justice'. ${ }^{6}$ Douzinas and Gearey, however, go further and describe 'jurisprudence' as 'the task of uncovering and pronouncing the truth about law' (Douzinas \& Gearey 2005, p. 5). This task, they argue, has been approached both internally and externally; internal approaches rely on the perspective of the judge or lawyer. External theories, by contrast, look for a wider non-legal explanatory context for the 'facts' expounded by the judges and lawyers; they look for a sociological and socio-legal context. External theories, they argue, have been 'demoted' in the Law School curriculum, as 'legal positivism has been the dominant and typically modernist internal approach' (ibid.). This has led, they argue, to the 'moral poverty of the jurisprudence of the twentieth century' (ibid.). I argue that the external approaches, or what I am calling 'alternative' (i.e., to legal positivism) approaches to law are necessary so that we, and our students, might discover alterative truths about the law and about society.

\subsection{Methodology versus theory versus method?}

Talking of canons and textbooks as tools for students raises another question: are we talking about theory or about methodology? And what about method? There has been a burgeoning of late in books on legal methods - and we certainly teach courses on law and method to our students. 'Methodology' undoubtedly has theoretical connotations. So, for instance, a legal positivist methodology will use ideas from the 'theory' of legal positivism - that all law is created and laid down ("posited') by a law-making authority, that the validity of a rule of law lies in its formal legal status (not its relation to morality or other external validating factors - i.e., law is self-referential), that there is a concern with social standards that are recognized as authoritative: judicial decisions, legislation, custom. ${ }^{7}$ This theoretical perspective will then inform the types of questions that a legal positivist will be interested in asking - questions such as, What is the law? What does the social situation look like? And it also influences what they will not ask: What ought the law to be? Or, how is it the way it is - taking into account social, political and philosophical factors? In the same way, a postcolonial methodology will use ideas from postcolonial theory - such as challenging the taken for granted assumptions and naturalized categories of knowledge that are produced by the promotion of Western values. ${ }^{8}$ The types of generalized questions that are relevant for a postcolonial critique might therefore be: How does the law subordinate or silence people from the Global 'South' and 'Third' World? What violences are hidden by law's claim to race or culture neutrality?

6 Ratnapala 2009, p. 3. As Ratnapala also highlights, 'jurisprudence' can of course also be used to 'refer to the interpretation of the law given by a court' (p. 3).

7 See the description of 'legal positivism' in Cryer, Hervey \& Sokhi-Bulley 2011, p. 37-39.

8 For an example of 'applying' postcolonial theory to human rights, see Doty 1996; Mutua 2002; Rajagopal 2003. 
My point here is that methodology is not about 'high theory' - it is not about 'being a theorist'. It is, rather, about using the tools that theory, or different theories, provide to enable one to determine which are the right questions to ask for the particular project one is interested in. So, for instance, one does not need to 'be a Foucauldian' to use ideas of disciplinary power or governmentality to study an aspect of human rights law. Nor does one have to be loyal to only one particular theoretical, or methodological, perspective. It is of course possible to think like a poststructural feminist or to have a methodology that shows you think like a legal positivist, a feminist and a Marxist - though these positions raise inevitable tensions that must be negotiated by the researcher or student. There is the basic and obvious point that one must be true to the idea, to the theory. But I suggest that different theories, or approaches, collectively provide a toolbox of skills that we can take from (as researchers) and teach our students to use (as educators). This is 'not', as Peters states, 'a "shopping-mall approach to 'method"' but a precondition for informed criticism'. 'There is also a danger, when trying to teach methodology, with using the term 'theory'. Experience shows that it scares off students (and in some cases the educators also!). They associate the term with high theory/philosophy/jurisprudence - and not with a toolbox of ideas that provides them with the skills they need to be successful lawyers.

It is worth noting that as well as a distinction between methodology and theory, a distinction can also be made between methodology and 'method'. A method has empirical and sociological connotations - so, is the method a qualitative or quantitative analysis? What methods of data collection are used - documentary analysis, case studies, observation, interviews, for example? It is essentially about what you do in a project, as opposed to how you think it. ${ }^{10}$ Most, if not all, universities will teach courses on 'research methods'. Here students usually learn about qualitative methods - for example, how to conduct (expert) interviews. They would engage in questions such as 'What is qualitative interviewing?', 'Why interview' and 'What are the purposes of interviews', 'What kinds of information can we obtain from interviews', 'How to prepare an interview guide', 'How to select interviewees', 'How to carry out data collection and interview documentation', etc. ${ }^{11}$ They also learn about quantitative methods - such as surveys and questionnaires, using analytic tools such as cross-tabs, correlation and regression and SPSS. ${ }^{12}$

Interestingly, there has been a burgeoning of late in law books on method. Mike McConville and Wing Hong Chui's Research Methods for Law concentrates on making 'available methods of research - legalistic, empirical, comparative and theoret-

$9 \quad$ Peters 2001, p. 37, quoting Koskenniemi.

10 See further Cryer, Hervey \& Sokhi-Bulley 2011 and also Watkins \& Burton 2013, p. 2-4.

11 'Techniques and Methods in Law and the Social Sciences', LAW7002, March-May 2013 - compulsory module, LLM in Law and Governance, Queen's University Belfast. Available at http:// www.law.qub.ac.uk/schools/SchoolofLaw/FileStore/Filetoupload,422055,en.pdf (last accessed 18 November 2013).

12 Ibid. SPSS, known previously as Statistical Package for the Social Sciences, is the most commonly used programme for the statistical analysis. For a standard guide to using SPSS written for social scientists, see Acton et al 2009. 
ical' accessible to law students (McConville \& Chui 2007, p. 5); each chapter outlines a particular research 'method' within law, and helpfully and interestingly uses actual research projects as examples to illustrate how the method can be used to conduct legal research (p. 7). 'Method' and 'methodology' appear to be used interchangeably. Dawn Watkins and Mandy Burton's Research Methods in Law addresses the question of method versus methodology directly - and asserts that whilst the contributors may not agree on the precise and different definition of these terms, 'all of them agree that establishing an appropriate theoretical basis for a research project is as important as determining the appropriate method/s for carrying out the research' (Watkins \& Burton 2013, p. 2-3). The book offers a 'challenge [to] readers who are intending to take a pure, doctrinal approach to their research to provide a justification for the reason for doing so' (p. 4). Whether doctoral research could and ought to be underpinned by elements of social sciences is considered by the contributors in Mark Van Hoecke's Methodologies of Legal Research: What Kind of Discipline for What Kind of Method? Should legal doctrine be merged with the social sciences? Van Hoecke suggests that Law should use these disciplines but not try to integrate them, so as to avoid problems of epistemology, of methodology and of research skills (Van Hoecke 2013, p. xiii). Whilst I disagree with this, I do agree with the self-reflexive sentiment of Roger Brownsword's question of 'what am I doing as a legal scholar in contract law?' in his chapter (Brownsword 2013, p. 133). It is crucial that 'the researcher is reminded of the need to be reflective and reflexive during the research process and to question whether the chosen methodology is the most appropriate for researching the chosen topic (McConville \& Chui 2007, p. 3).

I argue that methodology is therefore about 'how to think' a project. This is different to how to think about a project (method). I interpret methodology as a way of thinking, an attitude - it is therefore not as much about theory or method but about an approach, a perspective, or a lens through which to see a project. The reason the methodology is so vital is that it influences the hypothesis, research questions and sources used in a project. Arriving at one's research questions and 'deciding upon' a methodology is thus a reflexive and circular process, as Figure 1 illustrates: ${ }^{13}$ 
Figure 1 Deciding upon a methodology

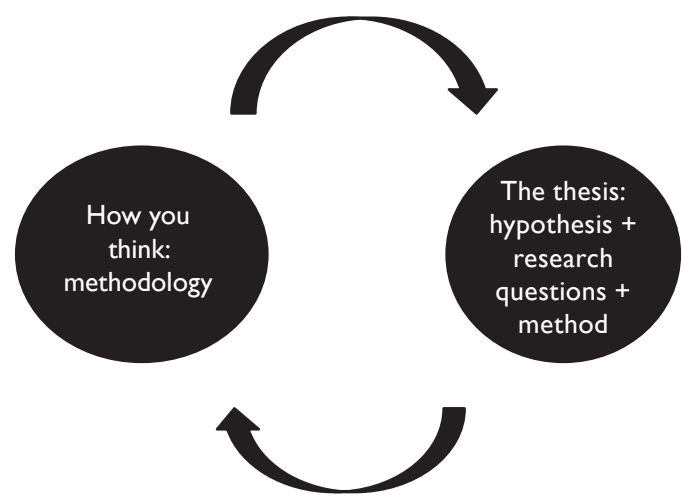

Methodology thus influences the thesis - i.e., the hypothesis, research questions and method - which in turn directly influences the critical discussion, the sources that will be used, the argument and the structure of a project. It is therefore vital that as educators we teach our students about methodology. Research is now an integral part of the curriculum for undergraduates and postgraduates alike, with coursework becoming an increasingly popular form of assessment (McConville \& Chui 2007, p. 2). Students at all levels require methodological skills for research. Methodology is the link from having a topic for a dissertation and turning that topic into a thesis by identifying the right questions for that person's interest, personality, and available sources. I am often asked in the talk that I refer to at the start of this paper, 'how do I choose a methodology'? My starting point in answer to this is that methodology stems from a personal viewpoint or attitude so, it is not a 'choice' in the sense that you simply 'add in and stir' any methodology to a project. The point I then make is that we all, obviously, think differently and so will be interested in different questions regarding the same thing. These different personal attitudes should be acknowledged (as methodology) and given a name in research projects. Most of the time students are not aware that, on the one hand, their attitude or ability to choose a methodology is impaired by having been disciplined and trained in a legal positivist tradition only and, on the other hand that their 'chosen' approach, if doctrinal, should be labelled legal positivist (it is fair to say that the majority of undergraduate and LLM-level dissertations are 'black-letter'; McConville \& Chui 2007, p. 4). This label is useful and necessary to determine as it will help them think critically about the types of questions they are interested in asking. Similarly, if they have enjoyed reading a feminist scholar let's say, they might benefit from being encouraged to use one of the array of feminist perspectives to think their ideas and arrive at suitable research questions. As Ann Peters states, 'methodological explicitness is preferable because it contributes to a transparency of argument' (Peters 2001, p. 37).

Students also ask whether there is more than one type of methodology, and if so, how many? In the Research Methodologies book, we present what we call 'the list' 
(Cryer, Hervey \& Sokhi-Bulley 2011, p. 10) - it is by no means an exhaustive list but one that we felt reflected the dominant and also what I call in this paper the 'alternative' methodological perspectives. We called the former the 'Main Jurisprudential Approaches' - i.e., legal positivism and natural law perspectives. The latter were called 'Extensions and Negations', which were split into two parts: first, the 'Modern and Critical Approaches' - which included governance, Marxism, critical theory, feminist perspectives, postcolonial theory, for instance and second, the 'law and' approaches - which included for example, law and geography, law and international relations, and law and geography (ibid.).

As the book explains, 'the list' was arrived at after much deliberation and agonizing (p. 11). It also acknowledges areas that are missing from the list - notably comparative law. This, it was decided, is arguably a subject in itself, with its own theories and methods (p. 12) ${ }^{14}$ We drew on various sources for inspiration, since there is something approaching an 'accepted cannon' of international law theories (such as Steven Ratner and Anne-Marie Slaughter's The Methods of International Law. ${ }^{15}$ Ratner and Slaughter define 'method' as 'the application of a conceptual apparatus or framework - a theory of international law - to the concrete problems faced by the international community' (Ratner \& Slaughter 2004, p. 3). This is what we understand in the book as 'methodology', 'theory' or 'approach'. Their list (legal positivism; New Haven school; international legal process; critical legal studies; international law and international relations; feminist jurisprudence; Third World approaches to international law; law and economics) has a similar starting point to the list in the book.

The 'extensions and negations' were so-labelled since they extend or depart from the traditional approaches. They are, in other words, 'alternative'. However, part of what I want to stress in this paper is that this does not make these 'other' approaches to (EU or international) law any less useful to students (or indeed researchers) than the mainstream or traditional approaches. A mainstream/alternative dichotomy suggests that that which comes under 'alternative' is lesser, or inferior, or lacking in importance. To use Kennedy's word, it is merely 'peripheral'. However, I argue that these alternative approaches present us with the opportunity of alternative truths. They allow us to change the research question of a project depending upon the lens - i.e., the perspective, or methodology used. I illustrate this below using an example exercise asked of our students. Before that, let me outline an example of an alternative methodology that I have personally found useful, and why.

\subsection{Governmentality as an 'alternative methodology'}

A perhaps awkward neologism, 'governmentality' is a term coined by Foucault in his later work to explain the power relations that make individuals govern(ment)able and thereby allow for the exercise of a regulatory, or governing, power (Foucault 2002a, p. 201). Thus,

15 For another overview of 'approaches' to international law, see also Peters 2001. 
'This word [government]must be allowed the very broad meaning it had in the sixteenth century. "Government" did not refer only to political structures or to the management of states; rather, it designated the way in which the conduct of individuals or of groups might be directed - the government of children, of souls, of communities, of the sick (...) To govern, in this sense, is to control the possible field of action of others' (Foucault 2002b, p.341; emphasis added).

Understood in this perhaps literal manner (the verb 'to govern' can literally mean 'to control or influence'; Concise Oxford Dictionary 1999), government refers to the 'conduct of conduct' (Gordon 1991, p. 1-2); a form of activity or practice that aims to shape, guide or affect the conduct of some person or persons. In a lecture given at the Collège de France in 1978, posthumously given the title 'Governmentality', ${ }^{16}$ Foucault presents his most concise definition of the term. He explains that 'governmentality' means three things (Foucault 2002a, p. 219-220): first, 'the ensemble formed by the institutions, procedures, analyses, reflections, calculations and tactics that allow the exercise of this very specific albeit complex form of power, which has as its target population'. Second, governmentality refers to 'the tendency that, over a long period and throughout the West, has steadily led to the pre-eminence over all other forms (sovereignty, discipline and so on) of this type of power, which may be termed "government". Third, governmentality is the (result of the) process by which the state gradually 'becomes governmentalized'.

For the purposes of this paper, it is important to understand that 'governmentality' can be understood as both the process of government (that is, as an 'art of government' itself; Foucault 2007, p. 205) and as a methodology (that is, as a 'rationality of government' - a way of thinking about the practice of government, and hence of whom or what is being governed, what governing is, whom or what can govern, and so forth; p. 106). It is a 'govern/mentality' (Barron 2005, p. 984). I describe governmentality as a methodology to understand various practices and processes in law. There is a large and growing number of scholars who use a governmentality perspective to understand the ways in which technologies of government operate - for instance in the context of crime control(Garland 1997, p. 173; Rose 2000, p. 321), ${ }^{17}$ healthcare (Rose 2007), immigration and asylum (Bigo 2007, p. 63; Darling 2011, p. 263; Inda 2006), e-Government (Morison 2010, p. 551), and new governance agencies and human rights (Sokhi-Bulley 2011, p. 139-156). What these contributions have in common is the use of governmentality as a methodology - not simply as a 'theory' (which it is not) but as a tool with which to better understand the 'thing' (e.g., interrogating the 1999 Immigration and Asylum Act and subsequent developments and presenting the UK border as a site of domopolitics - (Darling 2011); describing rights as technologies of governmentality that govern the global virtuous identity of the EU as a

16 Foucault 2002a. Also presented by Foucault as the fourth lecture in the course Security, Territory, Population (Foucault 2007, p. 87).

17 See also Rose and Miller (2008) on 'governing communities'. 
rights actor (Sokhi-Bulley 2011) that they are critiquing. Governmentality is thus a 'creative' concept and a creative methodology - meaning it is a flexible, openended and above all useful tool. It is essentially about satisfying that 'curiosity' - to 'find what surrounds us as strange and odd (...) to look at the same things in a different way'. It helps us to challenge typical conceptions of government as implying state power, sovereignty or hierarchy and examining instead the various technologies and tactics, the often mundane processes, through which power circulates in a heterarchical fashion.

Moreover, recent academic conferences have been built around the central Foucauldian themes of biopower and genealogy - note for example, the Law Culture and the Humanities annual conference of 2013, themed 'Sculpting the Human: Law, Culture and Biopolitics'; ${ }^{18}$ and, the Critical Legal Conference of 2009, themed 'Genealogies: Excavating modernities'. ${ }^{19}$ This illustrates that the label 'alternative' is perhaps limited in its appreciation of the type of literature that does engage with the less mainstream approaches to law - although the question still remains of how we communicate these to our students and this is what I come on to in the next section.

\section{Methodology as skill}

\subsection{Methodology and transferrable skills}

Thus far I have been trying to show that methodology is not just about theory or about method - it is also, and crucially, about a critical attitude. This attitude can be nurtured and disciplined - it can be taught and learned as a skill. Students nowadays want to know what they need to do to gain their degree so that they can go on and practice law. They respond to the language of 'skills'. I teach on a module called Legal Theory and face a constant challenge of having to explain the validity of theory to students, the majority of whom want to qualify as lawyers and practice. It means marketing 'theory' as a 'tool' - as a 'skill'. Similarly, I teach 'methodologies' as one of three 'skills sessions' on the main human rights module for postgraduates studying on the LLM in Human Rights. Without these (albeit brief) sessions, postgraduate students otherwise have no 'formal' exposure to methodologies before going on to write their end of year dissertation.

I use the terminology 'marketing as skills' slightly uneasily because of its management-speak connotations, but this is precisely what we are doing. Programmes such as the Personal Development Portfolio at Queen's ask students in their third and final year of undergraduate studies to define what they understand by 'transferrable skills' and whether they see 'critical analysis' or 'critique' as such a skill. ${ }^{20}$ It is interesting to observe that students often do not realize the skills they have

18 http://www.law.syr.edu/academics/centers/lch/conference.html (accessed 15 June 2013).

19 http://lsolum.typepad.com/legaltheory/2009/05/conference-announcement-critical-legal-confe rence-at-leicester.html (accessed 15 June 2013).

20 http://www.law.qub.ac.uk/schools/SchoolofLaw/Education/Undergraduates/PersonalDevelop mentPlanning/ (accessed 15 June 2013). 
learnt over the course of their law degree - both research skills (for example, how to find and cite a case; how to reference correctly; presentation skills) and personal development skills (for example, time management; punctuality; group or teamwork). ${ }^{21}$ It is perhaps relatively easy for them to see how these might translate, or 'transfer', to an employment context. What they do not generally see with as much ease is how learning about different legal theories, or methodologies, might help them in the workplace.

A 'skill' is literally defined as 'the ability to do something well; expertise'. ${ }^{22}$ By learning about (alternative) methodologies, students are becoming experts in how to (better) understand law. They are developing their conceptual (ideas), creative (originality) and critical (evaluation) skills. They are thus gaining the ability to challenge assumptions about the law; to consider alternative questions on a topic of law; they are therefore learning the ability to create alternative truths. Alternative methodologies provide a toolbox of approaches to a problem/research question - the 'tool' may be governmentality, or feminism, or Marxism, etc. The point is that the problem or research question can be approached using tools other than the mainstream approaches. And students should be exposed to all the tools in the toolbox - so they might decide for themselves which is the most appropriate for how they think. Legal research methodologies should thus be taught as a skills or tools within 'a tool-box which others can rummage through to find a tool they can use however they wish in their own area' so that our students might be 'users, not readers'. ${ }^{23}$

The question of how this might be useful to the practicing lawyer still remains. Many students view 'law as craft', where 'practical professionalism' is seen as an alternative to adopting an external academic discipline (e.g., economics, sociology, psychology or philosophy; Dagan \& Kreitner 2011, p. 671, 677, 689-690). Here I suggest that methodology is practice - as a (critical) attitude, it will influence how you practice the law. How well you are able to identify not only what the law is but to challenge its assumptions and to interrogate them. It means to take on the challenge of not becoming the docile (if still successful) lawyer, as I will explain further below.

\subsection{The critical attitude: searching for alternative truths}

The students at the Research Methods workshops were fascinated to discover how the end product of a project can change depending on the questions you ask, so, depending on your methodology - that you can choose not be governed by what I'm calling traditional or black-letter approaches. One of the exercises during the workshops was to draft a potential outline for a dissertation topic. The

21 Kennedy (2004, p. 31) gives a summary of 'simple but important things' (i.e., skills) that law students learn.

22 Oxford English Dictionaries Online: http://oxforddictionaries.com/definition/english/skill?q=skill (accessed 2 July 2013).

23 Foucault 1994, p. 523-524, commenting on his work as 'fragments' to be used as part of a 'critical attitude'. 
students were asked to identify their research questions and their approach/perspective /methodology. They were then asked to swap 'thinking hats' (De Bono 1992) and reconceptualise their projects from an entirely different perspective to show how the thesis would look completely different (Cryer, Hervey \& Sokhi-Bulley 2008, p. 49). So, for instance, if you are doing a legal positivist analysis into how human rights discourse has evolved in the European Union, for instance, how do your research questions change if you adopt a postcolonial approach - where you are suddenly interested not in questions about what the law is and the rule of law but in questions of genealogy, of power relations, of 'otherness'.

We conducted a similar exercise with our final year undergraduates at my institution - we asked them to think about writing a feature piece on the 'London Riots' of August 2011, identifying key issues, which we all agreed on as being: race, class, poverty, male, youth and crime. We then asked them to write their piece from a legal positivist perspective, a CRT perspective, a feminist perspective and a Foucauldian perspective and to identify how the approach influences the questions you ask, which influences your research project as a whole. That is, the perspective influences the effect of the analysis - what you are trying to show or prove in the project. So, for instance, looking at the riots from a legal positivist perspective would necessitate asking: What law applies? What laws were violated? What decisions did the courts make? The effect of this type of questioning, of this type of methodology is to then make a statement that qualifies these questions - for example, that the riots resulted in the criminalization of this behaviour and in some cases the handing out of disproportionate criminal sentences (note the case of $R v$ Blackshaw). ${ }^{24}$ Examining the riots from a feminist perspective might prompt questions such as: Did the riots reflect a gender issue? Did they normalize male violence (women being portrayed as the 'broom brigade' and the tea servers)? Did they stereotype the mothers of the delinquent youth as 'bad parents'? The effect of this type of questioning, of this type of methodology, is to be able to state, for instance, that the riots did normalize male violence.

The point is that different perspectives (or methodologies) on a problem/topic create 'alternative truths' about them because they tell the same story in a different way. Many of the students were taken aback by how the story of the riots changed depending on the perspective used. It is an important skill, this article argues, to be able to look at the same things in a different way, in an alternative way, in a more critical way.

\subsection{Moving beyond the docile, successful lawyer}

Matthew Ball comments that although it is often argued that law schools provide a negative, competitive, and conservative environment for students, pushing them towards self-interested, vocational concerns, this is nevertheless a productive process (Ball 2012, p. 103). Using Foucault's work on the government of the 
self, he argues that far from law students being repressed, they engage in a selffashioning process that allows them to act effectively as legal personae.

So, perhaps I am wrongly concerned with importance of teaching critical legal education. Perhaps if the students govern themselves to become successful legal practitioners without reading Foucault or Derrida or Habermas, for instance, we have been successful educators. My problem with this is the resultant docility that governmentality within law schools engenders: the docile, successful lawyer that has not been encouraged to 'think about the same things in a different way' or, then in turn, to engage in critique and to resist the dominant paradigm. An awareness of methodology can be in itself a form of 'resistance': Kennedy (2004) uses this idea to argue that educating students on what he calls 'theory' can be used to resist the reproduction of a hierarchy (that already exists in legal education) in the practice of law and in society.

\section{Conclusion}

What does 'resistance' mean in this context? It means behaving differently - a 'counter-conduct', or 'struggle against the processes implemented for conducting others' (Foucault 2007, p. 201; my emphasis). These processes include the way in which legal education operates - often without exposing students to critical methodologies that would provide them with the skills to view (legal) issues, to solve (legal) problems differently. We need a sort of 'revolt of conduct' (ibid.) in legal education, such that courses on theory and methodology are not relegated to the periphery; such that methodology is seen as an attitude and, perhaps more crucially in educational terms, as a skill. To echo Hanoch Dagan and Roy Kreitner, 'the implication would be that while people in the law school could do anything in the way of scholarship, they would also have to speak legal theory if not with native proficiency then at least as a second language' (Dagan \& Kreitner 2011, p. 10). Law Schools should aspire to teach legal theory as methodology and as skill. Classes on legal research methods should discuss methodology as an attitude; they should feature alternative methodologies and encourage a critical attitude in students. McConville and Chui alert us to 'evidence that law schools in the United Kingdom, the United States and elsewhere are offering new postgraduate programmes (such as socio-legal studies, feminist legal studies, critical legal studies and new approaches to international law) that encourage an interdisciplinary approach to the study of law' (McConville \& Chui 2007, p. 5). This is of course an example of positive developments in the area of critical legal education and should be encouraged.

What will this resistance achieve? It will hopefully produce better quality work from our students, as they exercise their conceptual, critical and creative skills. It will produce a less docile subject - the student who has the knowledge, who has been 'emancipated' by that knowledge (to use Habermas' wording) and who can therefore say that she does not want to be conditioned to think like that. The student that is not afraid to engage in 'a different form of conduct (...) wanting to be 
conducted differently, by other leaders (conducteurs) and other shepherds, towards other objectives and forms of salvation and through other procedures and methods' (Foucault 2007, p. 194-195). These are the alterative procedures, or methodologies, that depart from legal positivism and are all too often removed from legal education.

\section{References}

\section{Acton et al 2009}

C. Acton, R. Miller, J. Maltby, and D. Fullerton, SPSS for Social Scientists (2nd ed) Palgrave Macmillan, Basingstoke 2009.

\section{Ball 2012}

M. Ball, "Becoming a "Bastion Against Tyranny". Australian Legal Education and the Government of the Self', Law and Critique 2012, p. 103-122.

\section{Barron 2005}

A. Barron, 'Foucault and Law', in: J. Penner et al. (eds.), Jurisprudence and Legal Theory. Commentary and Materials, Oxford: Oxford University Press 2005, p. 955-1034.

Bell 2013

J. Bell, 'Legal Research and the Distinctiveness of Comparative Law', in: M Van Hoecke, Methodologies for Legal Research. What Kind of Method for What Kind of Discipline?, Oxford: Hart 2013, p. 155.

Bigo 2007

D. Bigo, 'Security and Immigration. Toward a Critique of the Governmentality of Unease', Alternatives: Global, Local, Political 2002, p. 63-92.

\section{Brownsword 2013}

R. Brownsword, 'Maps, Methodologies and Critiques'. Confessions of a Contract Lawyer', in: M. Hoecke, Methodologies of Legal Research. Which Kind of Method for Which Kind of Discipline?, Oxford: Hart 2013, p. 133.

Burchill et al. 2009

S. Burchill et al., Theories of International Relations, Basingstoke: Palgrave Macmillan 2009.

\section{Concise Oxford Dictionary 1999}

The Concise Oxford Dictionary, 10th ed., Oxford: Oxford University Press 1999.

\section{Cryer, Hervey \& Sokhi-Bulley 2008}

R. Cryer, T. Hervey \& B. Sokhi-Bulley, 'Legal Research Methodologies in European Union and International Law: Research Notes (Part 2)', Journal of Contemporary European Research 2008, p. 48-51.

Cryer, Hervey \& Sokhi-Bulley 2011

R. Cryer, T. Hervey \& B. Sokhi-Bulley, Research Methodologies in EU and International Law, Oxford: Hart 2011.

\section{Dagan \& Kreitner 2011}

H. Dagan \& R. Kreitner, 'The Character of Legal Theory', Cornell Law Review 2011, p. 671-691.

\section{Darling 2011}

J. Darling, 'Domopolitics, governmentality and the regulation of asylum accommodation', Political Geography 2011-30, p. 263-271.

\section{De Bono 1991}

E. de Bono, Teach your Child How to Think, London: Viking 1992. 


\section{Doty 1996}

R.L. Doty, Imperial Encounter, Minneapolis: University of Minnesota Press 1996.

\section{Douzinas \& Gearey 2005}

C. Douzinas \& A. Gearey, Critical Jurisprudence. The Political Philosophy of Justice, Oxford: Hart 2005.

\section{Dunne, Kurki \& Smith 2013}

T. Dunne, M. Kurki \& S. Smith, International Relations Theories: Discipline and Diversity, Oxford: Oxford University Press 2013.

\section{Foucault 1994}

M. Foucault, 'Prisons et asiles dans le méchanisme de pouvoir', in: M. Foucault, Dits et Ecrits II, Paris: Gallimard 1994, p. 523-524.

\section{Foucault 1997}

M. Foucault, 'What is Critique?', in: M. Foucault, The Politics of Truth (S. Lotringer and L. Hochroth, eds.), Los Angeles, CA: Semiotext(e) 1997, p. 24.

\section{Foucault 2000}

M. Foucault, 'The Masked Philosopher', in: M. Foucault, Ethics. Volume 1: Subjectivity and Truth: Essential Works of Foucault 1954-1984 (P. Rabinow, ed.; R. Hurley, trans.), London: Penguin 2000, p. 321, 325.

\section{Foucault 2002a}

M. Foucault, 'Governmentality', in: M. Foucault, Power: Volume 3: Essential Works of Foucault 1954-1984 (J. Faubion, ed.; R. Hurley, trans.), London: Penguin 2002, p. 201.

\section{Foucault 2002b}

M. Foucault, 'The Subject and Power', in: M. Foucault, Power: Volume 3: Essential Works of Foucault 1954-1984 (J. Faubion, ed.; R. Hurley, trans.), London: Penguin 2002, p. 326, 341.

\section{Foucault 2007}

M. Foucault, Security, Territory, Population (M. Senellart, ed.; G Burchell, trans.), Basingstoke: Palgrave Macmillan 2007.

\section{Garland 1997}

D. Garland, 'Governmentality and the Problem of Crime', Theoretical Criminology 1997, p. 173-214.

\section{Gordon 1991}

C. Gordon, 'Governmental Rationality. An Introduction', in: G. Burchell et al., The Foucault Effect: Studies in Governmentality, Chicago: University of Chicago Press 1991, p. 1, 2.

\section{Habermas 1966}

J. Habermas, 'Knowledge and Interest', Inquiry. An Interdisciplinary Journal of Philosophy 1966-9, p. 285-300, quoted in Minkkinen 2013, p. 119.

\section{Hart 2012}

H.L.A. Hart, The Concept of Law, Oxford: Oxford University Press 2012.

\section{Hutchinson 2013}

T. Hutchinson, 'Doctrinal Research: Researching the Jury', in: D. Watkins \& M Burton (eds.), Research Methods in Law, Abingdon: Routledge 2013, p. 7.

\section{India 2006}

J.X. Inda, Targeting Immigrants: Government, Technology, and Ethics, Oxford: Blackwell 2006.

\section{Kennedy 2004}

D. Kennedy, Legal Education and the Reproduction of Hierarchy.A Polemic Against the System, New York and London: NYU Press 2004. 


\section{McConville \& Chui 2007}

M. McConville \& W.H. Chui, Research Methods for Law, Edinburgh: Edinburgh University Press 2007.

\section{McCoubrey \& White 1999}

H. McCoubrey \& N. White, Textbook on Jurisprudence, Oxford: Blackstone Press 1999.

\section{Minkkinen 2013}

P. Minkkinen, 'Critical Legal "Method” as Attitude', in: D. Watkins \& M. Burton (eds.), Research Methods in Law, Abingdon: Routledge 2013, p. 119.

\section{Morison 2010}

J. Morison, 'Gov 2.0. Towards a User Generated State?, Modern Law Review 2010, p. 551-577.

\section{Mutua 2002}

M. Mutua, Human Rights: A Political and Cultural Critique, Philadelphia: University of Pennsylvania Press 2002.

\section{Oxford English Dictionaries Online}

Oxford English Dictionaries Online: http://oxforddictionaries.com/definition/english/ skill?q=skill.

\section{Penner \& Melissaris 2012}

J. Penner \& F. Melissaris, McCoubrey and White's Textbook on Jurisprudence, Oxford: Oxford University Press 2012.

\section{Penner et al. 2005}

J. Penner et al. (eds.), Jurisprudence and Legal Theory. Commentary and Materials, Oxford: Oxford University Press 2005.

\section{Peters 2001}

A. Peters, 'There is Nothing more Practical than a Good Theory. An Overview of Approaches to International Law', German Yearbook of International Law 2001, p. 25-37.

\section{Rajagopal 2003}

B. Rajagopal, International Law From Below. Development, Social Movements and Third World Resistance, Cambridge: Cambridge University Press 2003.

\section{Ratnapala 2009}

S. Ratnapala, Jurisprudence, Cambridge: Cambridge University Press 2009.

\section{Ratner \& Slaughter 2004}

S. Ratner \& A.-M. Slaughter, The Methods of International Law, Buffalo, NY: ASIL/ Hein 2004.

\section{Rose 2000}

N. Rose, 'Government and Control', British Journal of Criminology 2000, p. 321-339.

\section{Rose 2007}

N. Rose, The Politics of Life Itself. Biomedicine, Power, and Subjectivity in the Twenty-First Century, Princeton: Princeton University Press 2007.

\section{Rose \& Miller 2008}

N. Rose \& M. Miller, Governing the Present, Cambridge: Polity Press 2008.

\section{Sokhi-Bulley 2011}

B. Sokhi-Bulley, 'Governing (Through) Rights. Statistics as Technologies of Governmentality', Social and Legal Studies 2011, p. 139-155.

Steans et al. 2010

J. Steans et al., An Introduction to International Relations Theory. Perspectives and Themes, Harlow: Longman 2010. 


\section{Van Hoecke 2013}

M. Van Hoecke, Methodologies of Legal Research. Which Kind of Method for Which Kind of Discipline?, Oxford: Hart 2013.

\section{Watkins \& Burton 2013}

D. Watkins \& M. Burton, Research Methods in Law, Abingdon: Routledge 2013. 